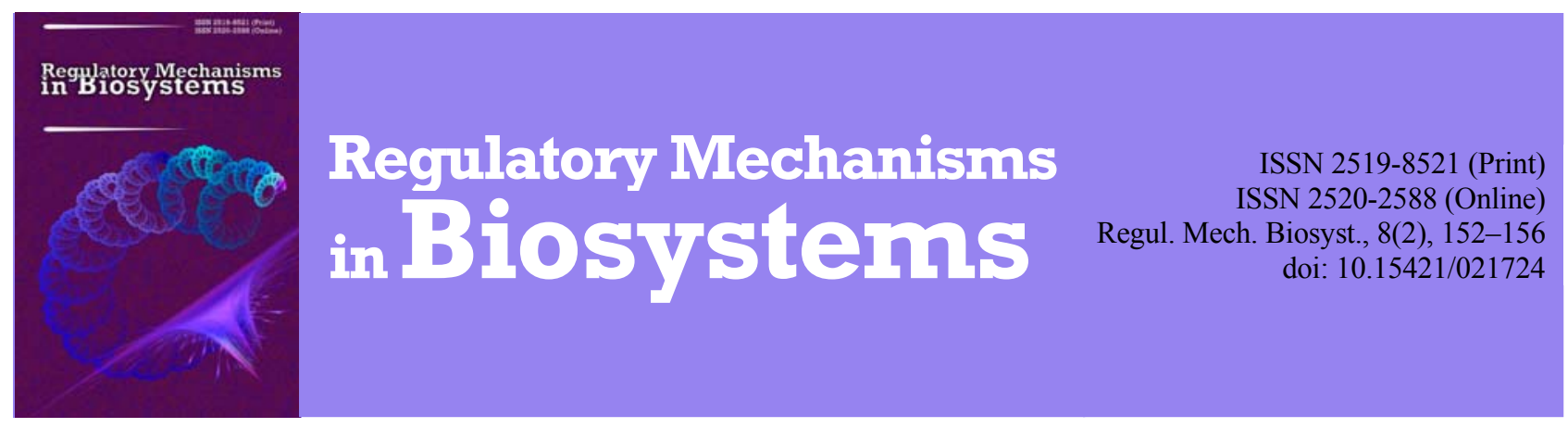

\title{
Peculiarities of the influence of antihypertensive therapy on endothelial function, oxidative stress and immune activation in obese patients
}

\author{
T. V. Ashcheulova, N. N. Gerasimchuk \\ Kharkiv National Medical University, Kharkiv, Ukraine
}

Article info

Received 17.03.2017

Received in revised form 22.04.2017

Accepted 25.04.2017

Kharkiv National Medical University, Nauky Ave., 4, Kharkiv, 61022, Ukraine. Tel.: +38-096-120-68-72. E-mail:

nino.gerasimchuk@gmail.com

\begin{abstract}
Ashcheulova, T. V., \& Gerasimchuk, N. N. (2017). Peculiarities of the influence of antihypertensive therapy on endothelial function, oxidative stress and immune activation in obese patients. Regulatory Mechanisms in Biosystems, 8(2), 152-156. doi:10.15421/021724
\end{abstract}

This article aims to improve the combined antihypertensive therapy on the basis of studying the antioxidant properties of bisoprolol and indapamid, their impact on endothelial dysfunction (ED) and pro-inflammatory cytokines activity in hypertensive patients with overweight and obesity. A combination of a $\beta$-blocker (BAB) with a diuretic (D) (bisoprolol 2.5, 5, $10 \mathrm{mg}$ and indapamid $1.5-2.5 \mathrm{mg}$ /day) was prescribed to 102 patients with essential hypertension of $1-3$ grades, 30 to 65 years old (mean age $-54.54 \pm 0.91$ years), who previously had not been receiving regular antihypertensive therapy. The daily dose of bisoprolol was administered by continuous slow titration, starting with low doses of $1.25 \mathrm{mg}$ /day. Of the patients 82 were women and $20 \mathrm{men}$, the duration of disease averaged $9.0 \pm 0.71$ years. The control group included 16 healthy subjects matched for age and sex. The level of stable terminal metabolites of nitric oxide $\mathrm{NO}$ (nitrite $\mathrm{NO}_{2}{ }^{-}$and nitrate $\mathrm{NO}_{3}{ }^{-}$), the concentration of S-nitrosothiol and NO-synthases (NOS), SOD, and catalase activity was determined biochemically. The contents of serum 8 -iso-PgF2 $\alpha$ (8-isoprostane), TNF-alpha and its type I soluble receptor (sTNF- $\alpha \mathrm{RI}$ ) were determined in all subjects using the "8-isoprostane ELISA" (Usbiological, USA), "ProCon TNFa" (Protein Contour, Russian Federation) and "sTNF-RI EASIA" (BioSource Europe SA, Belgium) ELISA kits, respectively. During the course of combined antihypertensive therapy we observed a significant decrease of S-nitrosothiols levels, i-NOS activity, reduction of TNF- $\alpha$ type I of its soluble receptor (sTNF- $\alpha$ RI), and oxidative stress marker -8 -iso-PgF2 $\alpha$ in the examined patients. Nitrites and nitrates serum levels, activity of e-NOS, superoxide dismutase and catalase, by contrast, were increased in patients with hypertension and concomitant obesity. These changes may reflect the fact that against the background of the therapy there was a reduction in tension of oxidative stress, which leads to an improvement in endothelial function. Significant reduction ratio of TNF- $\alpha / \mathrm{sTNF}-\alpha \mathrm{RI}$ shows suppression of autoimmune and apoptotic activity in patients under treatment. Thus, the improvement of endothelial function, a significant decrease in autoimmune activation due to lower tension of oxidative stress in the examined patients optimizes use of a combination of bisoprolol and indapamid for differentiated therapy in hypertensive patients with obesity.

Keywords: nitric oxide; S-nitrosothiol; endothelial and inducible NO-synthase; tumor necrosis factor-alpha and its soluble receptor type I; 8-isoprostane; superoxide dismutase; catalase

\section{Introduction}

Hypertension occupies a leading place among the causes of cardiovascular and cerebrovascular mortality. Meta-analyses of clinical trials have shown a significant reduction in risk of coronary events and stroke in cases of intensive lowering of blood pressure (BP) in comparison to patients with a lesser decrease in blood pressure (Ruilope, 2005), which indicates the expediency of developing new approaches to diagnosis, timely and adequate therapy of this disease.

Published in 1997, a report by the World Health Organization (WHO) emphasizes that the prevalence of obesity is a rapidly progressing social problem of our time which has adverse effects on our health that cannot be neglected. Numerous clinical studies have established the relationship of high blood pressure with increasing body weight. In particular, in the INTERSALT study, carried out in 52 population groups, there was a direct correlation between body mass index (BMI) and elevated blood pressure (Dyer et al., 1994).

In one particularly large-scale study, the Hypertension Control Program found that $50 \%$ of surveyed middle-aged overweight subjects suffered from hypertension (EH), and 2/3 cases of the hypertension were associated with obesity (Stamler et al., 1987). According to the Framingham study. $78 \%$ of men and $65 \%$ of women who are obese suffer from hypertension. Thus, with an increase in body weight of $4.5 \mathrm{~kg}$ systolic blood pressure increases by an average of $4 \mathrm{~mm} \mathrm{Hg}$ (men $-4.4 \mathrm{~mm} \mathrm{Hg}$, for women $-4.2 \mathrm{~mm}$ $\mathrm{Hg}$ ), so weight gain of $1 \mathrm{~kg}$ is accompanied by an increase in blood pressure by $1 \mathrm{~mm} \mathrm{Hg}$ (Alisson et al., 1997). These data are confirmed by studies of the Swedish Obesity Study (Sjostrom and Lissner, 1997) that $44-51 \%$ of individuals with obesity suffered from essential hypertension. Consequently, the increase in body weight is a potential risk factor for essential hypertension.

Recently the term "obesity induced hypertension" ("hypertension induced by obesity") has been coined. The pathogenesis of the hypertension associated with obesity is a multicomponent process, including an increase in circulating blood volume, vasoconstriction, hyperactivity of the sympathetic and renin-angiotensin-aldosterone system (RAAS), metabolic disorders. One of the early phases of the pathogenesis of this combined pathology is the development of endothelial dysfunction (ED). Elevated levels of angiotensin 
secreted by the adipocytes, is an important link between visceral obesity and ED, as evidenced by the correlation of the ratio of the "circumference of waist/circumference of hips" with the level of mRNA angiotenzinoguena visceral and subcutaneous adipose tissue. The subsequent increase of production of angiotensin II at the tissue level stimulates the secretion of superoxide, a leading factor in the etiology of ED. The subsequent increase of production of angiotensin II at the tissue level stimulates the secretion of superoxide, a leading factor in the etiology of endothelial dysfunction (Lahera et al., 2011; Chow and Allen, 2016; Chaudhary and Chaudhary, 2017). Currently, the leading role of the endothelium, and nitric oxide in the pathogenesis of cardiovascular complications hypertension is being investigated. Endothelial dysfunction (ED) is one of the main links in the pathogenesis of hypertension.

The endothelium is regarded, on one hand, as a target organ that is primarily damaged with an increase in blood pressure, and on the other - as a direct source of its increase. ED may be a consequence of reduction in NO synthesis by endothelial cells, as well as the activation of its degradation in the conditions of oxidative stress (OS).

The leading role in reducing endothelium-dependent vasodilation is taken by to the intracellular OS as free radical oxidation dramatically reduces the production of $\mathrm{NO}$ by endothelial cells (Kovaljova et al., 2005; Ashcheulova et al., 2007). Also ED is associated with high risk of cerebrovascular complications of hypertension: encephalopathy, transient ischemic attacks, ischemic stroke (Allison, 2016). Endothelial dysfunction and OS are becoming the new therapeutic targets in the treatment of hypertensive patients. Their manifestations are reduced by the action of endogenous and exogenous antioxidants that restore endothelial function by preventing the interaction of excess nitric oxide produced in pathological conditions with superoxide anions. It should be noted that the analyses of pharmacological properties of antihypertensive drugs pay little attention to this aspect. According to some researchers, OS can be a promotor of activation of the proinflammatory cytokines system. Among the pro-inflammatory cytokines, the tumor necrosis factor- $\alpha$ (TNF- $\alpha)$ deserves particular attention in context of hypertension (Azra and Feely, 2005; Bautista et al., 2005; Ashcheulova et al., 2007; Ambrosova et al., 2009; Kovaljova et al., 2015).

Thus, Zahorska-Markiewiez et al. (2001) was found in the blood of patients with essential hypertension an increased content of C-reactive protein (CRP) and TNF- $\alpha$. Hemodynamic stress caused by hypertension,is a stimulus of increased release into the blood of proinflammatory cytokines, including TNF- $\alpha$ (Kovaljova and Ashcheulova, 2002; Arroyo-Espliguero et al., 2009), which, in turn, can modulate the structure and function of the cardiovascular system. Thus, TNF- $\alpha$ is able to suppress myocardial contractility through blockade of $\beta$-adrenergic signals, increase the content of nitric oxide in the myocardium and cause changes in the homeostasis of intracellular calcium. Insulin resistance (IR) as one of the components of metabolic syndrome $\mathrm{X}$ is a link between ED and abdominal obesity, presumably through the system of nitric oxide, namely: endothelial NO increases glucose uptake by muscle cells (Li et al., 2012; Kovaljova et al., 2015).

The most important precondition for the maximum reduction in cardiovascular risk in hypertension is achieving the target BP, which may be a problem in presence of overweight and obesity. In many cases there is a need for combination of two antihypertensive drugs that should be metabolically neutral (Kovaljova et al., 2005; Neutel, 2011).

Thus, the scientific justification of treatment regimens for hypertensive patients with overweight and obesity, the study of the antioxidant efficacy of combined antihypertensive therapy is extremely relevant and important for today's practical healthcare. Despite the large number of antihypertensive drugs and the scientific study of the principles of treatment of patients with hypertension, it would be a mistake to assume that the problem is completely solved.

The research presented in this article aims o improve the combined antihypertensive therapy on the basis of studying the antioxidant properties of $\beta$-adrenoblocker (bisoprolol) and diuretic (indapamid), their impact on endothelial dysfunction and proinflammatory cytokines activity in hypertensive patients with overweight and obesity.

\section{Materials and methods}

A combination of a $\beta$-adrenoblocker (BAB) and diuretic (D) (bisoprolol 2.5-10.0 mg/day, and indapamid 1.5-2.5 mg/day) was prescribed to 102 patients with essential hypertension of 1-3 grades, from 30 to 65 years old (mean age -54.5 years), who previously had not been receiving regular antihypertensive therapy. The daily dose of bisoprolol was administered by continuous slow titration, starting with low doses of $1.25 \mathrm{mg} /$ day. Gradually the dose was increased to the maximum tolerated or target under the control of clinical parameters, especially blood pressure and heart rate (HR). Of these, 82 of the patients were women and 20 were men, the duration of the disease was on average $9.0 \pm 0.71$ years. The control group included 16 healthy subjects matched for age and sex.

Fasting blood was taken for research the day after the patient's admission to hospital, 12-18 hours after eating. In a part of this group (48 persons) the study was conducted after 12-14 days of inpatient treatment on the background of antihypertensive therapy and 2 months after the start of treatment. Blood sampling was performed from the cubital vein. All patients were similar in terms of physical activity, did not take any nitro-containing drugs, and did not eat foods rich in nitrates and nitrites.

On the basis of a complex clinical and instrumental examination, verification of the diagnosis and estimation of the hypertension grade was performed according to the criteria recommended by the European Society of Hypertension (ESH) / European Society of Cardiology (ESC) (2013). Exclusion criteria, in addition to secondary hypertension, included associated inflammatory and endocrine disorders as well as other conditions that could have an impact on the activity of oxidative processes. Thus 18 patients were diagnosed with essential hypertension of 1 degree, 29 patients with 2 degree and 55 patients with 3 degree hypertension.

In addition to the standard examination protocol, anthropometric measurements (height, weight, waist and hips circumference) were taken with the calculation of body mass index (BMI), waist to hips ratio $(\mathrm{W} / \mathrm{H})$ in order to determine the presence of excess body weight and degree of obesity as well as type of fat distribution.

The surveyed patients had overweight or obesity of 1,2 and 3 degrees. Overweight occurred in 55 patients and obesity in 47 patients where obesity of 1 degree was observed in 16 patients, 2nd degree with 22 and 3rd degree in 9 patients.

Some patients were diagnosed with concomitant diseases such as coronary heart disease $(\mathrm{CHD})$ angina pectoris $\mathrm{I}(\mathrm{n}=2), \mathrm{II}(\mathrm{n}=8)$ and III $(n=11)$ functional class, and diffuse cardiosclerosis $(n=62)$. With 9 patients their anamnesis recorded an ischemic stroke, 7 myocardial infarction. In the study of the fundus of eye hypertensive angiopathy of the retina was found in 68 patients. Neurological examination showed the presence of dyscirculatory encephalopathy with asthenic-neurotic $(n=44)$, vestibular-ataxic syndromes $(n=22)$ and liquor hypertension $(\mathrm{n}=34)$. In 90 patients hypertension was complicated by heart failure (HF). HF I stage occurred in 20 patients, HF II-A stage was in 67 patients and 3 cases were with HF II-B stage. In 12 patients the signs of HF were not observed.

The endothelial functional state on the background of combined therapy was studied by evaluating the activity of endothelial and inducible NO-synthase, level of nitrites, nitrates and S-nitrosothiol $(n=48)$.

Determining the state of pro-oxidant and antioxidant systems in the dynamics of treatment in this group of patients was based on the analysis of 8-isoprostane level $(n=10$, control group $n=10)$, superoxide dismutase (SOD), and catalase $(n=48)$. According to the current data, 8-isoprostane (8-IP) is considered one of the most specific markers allowing assessment of the level of free radicals production with a sufficient degree of accuracy, reliability and reproducibility of the results. 8-IP is a product of metabolism in 
peroxidation of arachidonic acid which is isomerical to prostaglandin F2 $\alpha$ (Kovaljova et al., 2015).

Immune activation during therapy with bisoprolol and indapamid was assessed by evaluating the serum levels of TNF- $\alpha$ and its type I soluble receptor (sTNF- $\alpha \mathrm{RI}$ ) in all subjects. These indices may be used as the criteria for treatment efficacy in hypertensive patients with overweight and obesity.

The level of stable terminal metabolites of nitric oxide NO (nitrite $\mathrm{NO}_{2}^{-}$and nitrate $\mathrm{NO}_{3}{ }^{-}$), the concentration of S-nitrosothiol and NO-synthases (NOS), SOD, and catalase activity was determined biochemically. The general NOS activity was assessed according to L. Green's method by evaluation of nitrite anion formed after incubation.

The contents of serum 8-iso-PgF2 $\alpha$ (8-isoprostane), TNF-alpha and its type I soluble receptor (sTNF- $\alpha$ RI) were determined in all subjects using the "8-isoprostane ELISA" (Usbiological, USA), "ProCon TNFa" (Protein contour, Russian Federation) and "sTNFRI EASIA" (BioSource Europe SA, Belgium) ELISA kits, respectively.

Statistical analysis of the study results was performed using Statistica v. 6.0 (Statsoft Inc., USA). The obtained results are presented as mean value (Mean) \pm standard deviation (SD). Compliance the normal distribution of data Gause during visual analysis of categorized histograms and using the KolmogorovSmirnov test, Shapiro-Wilk and Lilieforsa. Hypotheses about the equality of general average were evaluated using Student's test.

\section{Results and discussion}

As a result of research, we have found a significant increase in the S-nitrosothiol, i-NOS, pro-inflammatory cytokines (TNF- $\alpha$, sTNF-RI) levels, as well as markers of oxidative stress - 8-iso$\mathrm{PgF} 2 \alpha$ in the observed patients. Levels of nitrites and nitrates, eNOS and SOD activity, on the contrary, were decreased in the serum of patients with essential hypertension and associated obesity. The tendency to reduction of the latter parameters in the observed patients vs control group was also revealed. When determining catalase activity, there were no significant differences compared with the control group (Table 1).

Table 1

Levels of S-nitrosothiol, $\mathrm{NO}_{2}^{-}, \mathrm{NO}_{3}^{-}$, i-NOS, e-NOS, TNF- $\alpha$, sTNF- $\alpha$ RI, 8-isoprostane, SOD and catalase activity in hypertensive patients with obesity vs control group

\begin{tabular}{lcc}
\hline \multicolumn{1}{c}{ Parameter } & Control group & The examinees patients \\
\hline S-nitrosothiol, mmol/l & $0.220 \pm 0.039$ & $0.440 \pm 0.163^{*}$ \\
$\mathrm{NO}_{2}^{-}, \mu \mathrm{mol} / \mathrm{l}$ & $14.2 \pm 1.8$ & $13.9 \pm 6.3^{* *}$ \\
$\mathrm{NO}_{3}^{-}, \mu \mathrm{mol} / \mathrm{l}$ & $24.1 \pm 2.5$ & $20.2 \pm 8.2^{* *}$ \\
$\mathrm{i}-\mathrm{NOS}, \mathrm{pmol} / \mathrm{min} . \mathrm{x}$ mg of protein & $0.208 \pm 0.089$ & $0.591 \pm 0.093^{*}$ \\
e-NOS, pmol/min. x mg of protein & $0.782 \pm 0.045$ & $0.739 \pm 0.100^{* *}$ \\
$\mathrm{TNF}-\alpha, \mathrm{pg} / \mathrm{ml}$ & $13.2 \pm 3.4$ & $115.2 \pm 19.6^{*}$ \\
sTNF- $\alpha \mathrm{RI}, \mathrm{ng} / \mathrm{ml}$ & $1.20 \pm 0.60$ & $2.17 \pm 0.12^{*}$ \\
8-isoprostan, ng/ml & $1.41 \pm 0.25$ & $17.15 \pm 3.12^{*}$ \\
SOD, $\mu \mathrm{catal} / \mathrm{l}$ & $0.54 \pm 0.05$ & $0.46 \pm 0.14^{* *}$ \\
Catalase, $\mu \mathrm{catal} / \mathrm{l}$ & $3.34 \pm 0.39$ & $3.39 \pm 1.54^{* *}$ \\
\hline
\end{tabular}

Note: ${ }^{*}-\mathrm{P}<0.05$ vs control group; ${ }^{*} *_{-} \mathrm{P}>0.05$ vs control group.
There was an increase in S-nitrosothiol serum levels and reduction of nitrites levels and nitrates levels of most persons with hypertension of the 3rd degree and obesity of the 3rd degree, which can serve as an important pathophysiological mechanism of endothelial dysfunction in conditions of oxidative stress.

In the group of patients with hypertension of the 3rd degree S-nitrosothiol serum levels increased by 2 times $(0.46 \pm 0.16$ vs $0.22 \pm 0.04)$ compared to control group $(\mathrm{P}<0.05)$. In the group of patients with hypertension and obesity of III degree S-nitrosothiol serum levels increased by 2.5 times $(0.55 \pm 0.11$ vs. $0.22 \pm 0.04)$ compared to control group $(\mathrm{P}<0.05)$ and by 1.3 times compared to patients overweight $(0.41 \pm 0.14 ; \mathrm{P}<0.05)$.

In the group of patients with hypertension of the $3 \mathrm{rd}$ degree nitrites levels $(13.6 \pm 6.2$ vs $14.2 \pm 1.8 ; \mathrm{P}>0.05)$ and nitrates levels $(19.7 \pm 7.6$ vs $24.1 \pm 2.5 ; \mathrm{P}<0.05)$ decreased by 1.04 times and by 1.2 times, respectively, compared to the control group. In the group of patients with hypertension and obesity of III degree nitrites serum levels $(9.7 \pm 3.5$ vs $14.2 \pm 1.8 ; \mathrm{P}<0.05)$ and nitrates serum levels $(13.8 \pm 5.2$ vs $24.1 \pm 2.5 ; \mathrm{P}<0.05)$ decreased by 1.5 times and by 1.7 times, respectively, compared to the control group (Gerasimchuk, 2008). The increase of S-nitrosothiol serum levels in patients with hypertension and overweight or obesity may be associated with increased activity of inducible NO-synthase.

Thus, the obtained results of the study confirm that one of the leading mechanism of the pathogenesis of essential hypertension associated with obesity is endothelial dysfunction, a manifestation of which is the decrease in the level of nitric oxide as an important factor of relaxation of the endothelium of blood vessels, increased activity of iNO-synthase and a decrease in the activity of eNO-synthase (Privalova, 2013). The development of endothelial dysfunction plays an important role in immunocompetent activation mediated by proinflammatory cytokines, particularly tumor necrosis factor- $\alpha$, and OS.

Under the influence of bisoprolol and indapamid, we observed changes in S-nitrosothiol, stable NO metabolites and NOS activity. This drug combination alters the activity of SOD, catalase, and 8-isoprostane level. The dynamics of mean values, of the assessed parameters during the combined antihypertensive therapy are presented in Table 2.

Analyzing the data obtained both after 14 days from the start of treatment and after 2 months of therapy, S-nitrosothiol serum levels decreased by $21.3 \%$ and $32.2 \%$ respectively $(0.34 \pm 0.13$ vs $0.50 \pm$ $0.17)$ compared to baseline $(\mathrm{P}<0.05)$. These changes may reflect the fact that the reduction of oxidative stress was taking place on the background of therapy. The latter is also proved by a significant increase of nitrites levels by $21.1 \%$ and $34.6 \%(19.0 \pm 7.1$ vs $14.1 \pm$ 7.7), as well as nitrates levels by $21.8 \%$ and $31.2 \%$ (27.2 \pm 7.6 vs $20.7 \pm 9.9$ from baseline) $(\mathrm{P}<0.05)$ after the period of hospital treatment and after 2 months of therapy, respectively.

In the group of patients with hypertension, a change in the ratio of NOS isoforms activity was observed during the course of bisoprolol/indapamid treatment. The activity of i-NOS was signifycantly reduced by $10.6 \%$ and $11.3 \%(0.55 \pm 0.07$ vs $0.62 \pm 0.06$ vs the group prior to treatment) after the period of hospital treatment and after 2 months of therapy, respectively, $\mathrm{P}<0.05$.

Table 2

Endothelial functional state and oxidative stress dynamics during the combined therapy with bisoprolol and indapamid in hypertensive patients with obesity

\begin{tabular}{|c|c|c|c|}
\hline Parameter & Before treatment, $n=48$ & The period of inpatient treatment, $n=48$ & After 2 months of treatment, $n=10$ \\
\hline S-nitrosothiol, $\mathrm{mmol} / \mathrm{l}$ & $0.46 \pm 0.15$ & $0.36 \pm 0.12 *$ & $0.34 \pm 0.13^{*}$ \\
\hline $\mathrm{NO}_{2}^{-}, \mu \mathrm{mol} / 1$ & $13.0 \pm 5.9$ & $15.8 \pm 5.3^{*}$ & $19.0 \pm 7.1^{*}$ \\
\hline $\mathrm{NO}_{3}^{-}, \mu \mathrm{mol} / 1$ & $18.8 \pm 7.8$ & $22.9 \pm 6.7^{*}$ & $27.2 \pm 7.6^{*}$ \\
\hline $\mathrm{i}-\mathrm{NOS}, \mathrm{pmol} / \mathrm{min} . \mathrm{x} \mathrm{mg}$ of protein & $0.61 \pm 0.07$ & $0.54 \pm 0.09 *$ & $0.55 \pm 0.07 *$ \\
\hline $\mathrm{e}-\mathrm{NOS}, \mathrm{pmol} / \mathrm{min}$. $\mathrm{x}$ mg of protein & $0.77 \pm 0.07$ & $0.81 \pm 0.09 *$ & $0.85 \pm 0.08^{*}$ \\
\hline 8-isoprostan, $\mathrm{ng} / \mathrm{ml}$ & $20.5 \pm 17.4$ & $14.7 \pm 13.4^{*}$ & $12.3 \pm 7.3 *$ \\
\hline $\mathrm{SOD}, \mu \mathrm{catal} / 1$ & $0.48 \pm 0.17$ & $0.60 \pm 0.20^{*}$ & $0.60 \pm 0.11^{*}$ \\
\hline Catalase, $\mu \mathrm{catal} / 1$ & $3.31 \pm 1.57$ & $4.48 \pm 1.35^{*}$ & $4.14 \pm 1.29 *$ \\
\hline
\end{tabular}

Note: ${ }^{*}-\mathrm{P}<0.05$ vs levels before treatment. 
The activity of e-NOS, on the contrary, showed a significant increase by $5.6 \%$ and $8.1 \%(0.85 \pm 0.08$ vs $0.79 \pm 0.06$ compared to the level before treatment) after 10-14 days and 2 months of therapy, $\mathrm{P}<0.05$. From the above it can be concluded that the treatment of hypertensive patients with overweight and obesity with $\beta$-adrenoblocker (BAB) and diuretic (D) (bisoprolol in combination with indapamid) leads to positive dynamics of NO pool increase throughout the treatment period, indicating the restoration of vasodilatory capacity.

Thus, the changes observed during the course of the above scheme of combined antihypertensive therapy may indicate the improvement of the functional state of endothelium.

During the treatment in hypertensive patients with overweight and obesity using a combination of bisoprolol with indapamid, we also observed a change in the SOD and catalase activity. The obtained data indicates that the SOD activity in the period of hospital treatment significantly increased by $26.7 \%$ after in-patient period and by $47.0 \%$ after 2 months of treatment $(0.60 \pm 0.11$ vs $0.41 \pm 0.11)$ compared to a group of patients before treatment, $\mathrm{P}<$ 0.05 . A significant increase in the catalase activity was also prominent both during the hospital treatment period, by $35.3 \%$ $(4.48 \pm 1.35$ vs $3.31 \pm 1.57, \mathrm{P}<0.05)$ and 2 months after the start of treatment - by $48.4 \%(4.14 \pm 1.29$ vs $2.49 \pm 1.04, \mathrm{P}<0.05)$.

Analysing the level of 8-isoprostane as the main marker of oxidative stress, a decrease of its serum level by $28.1 \%(14.7 \pm 13.4$ vs $20.5 \pm 17.4, \mathrm{P}<0.05)$ was observed during $10-14$ days of treatment in a hospital. After 2 months of treatment, 8-isoprostane levels had decreased by $58.4 \%$ (down to $12.3 \pm 7.3$ ) compared to baseline and 2.4 times, respectively, was below. These facts testify to the beneficial effects of the studied scheme of antihypertensive therapy on the level of 8-isoprostane.

Analysis of the pro-inflammatory cytokines activity showed that a 2-months treatment with a bisoprolol/indapamid led to $61.2 \%$ decrease of mean TNF- $\alpha$ levels by $70.5 \mathrm{pg} / \mathrm{ml}(44.8 \pm 8.2$ vs $115.2 \pm 19.6, \mathrm{P}<0.05)$ compared to baseline prior to treatment. sTNF- $\alpha$ RI showed the opposite trend, increasing its mean levels on $0.24 \mathrm{ng} / \mathrm{ml}(11.1 \%)(2.41 \pm 0.03$ vs $2.17 \pm 0.12)$ during the course of treatment. A significant decrease of the ratio TNF- $\alpha / \mathrm{sTNF}-\alpha \mathrm{RI}$ by $34.5(65.0 \%)(18.6$ vs 53.1$)$ indicates a preferential increase in the level of sTNF- $\alpha$ RI, along with a reduction of TNF- $\alpha$. Since the sTNF- $\alpha$ RI is a natural antagonist of TNF- $\alpha$, a decrease in this ratio shows the suppression of autoimmune and apoptotic activity in patients as a result of treatment.

During the treatment the patients experienced an improvement of general well being, the reduction of intensity and frequency of headaches, dizziness, pain in the heart region, fatigue, increase in the exercise tolerance. All patients who had been receiving this treatment were discharged from the hospital in satisfactory general condition. The treatment contributed to a significant reduction in blood pressure levels as well as heart rate (HR). The features of these changes on the background of bisoprolol/indapamid treatment are presented in Table 3.

In the group of patients treated with bisoprolol and indapamid, a reduction in the mean values of office systolic blood pressure by $38.8 \mathrm{mmHg}$ and office diastolic blood pressure by $25.3 \mathrm{~mm} \mathrm{Hg}$ was observed during the hospital treatment period. The average mean blood pressure level decreased by $29.8 \mathrm{~mm} \mathrm{Hg}$, pulse blood pressure - by $13.5 \mathrm{~mm} \mathrm{Hg}$, which corresponded to $23.1 \%, 25.1 \%$, $24.2 \%$, and $20.0 \%$ reduction, respectively, compared with the levels before the onset of treatment $\mathrm{p}<0.05$ for all parameters.

There was also a statistically significant decrease in average heart rate 8 beats (by $9.6 \%$ ).

The results obtained in the course of treatment with bisoprolol $(2.5,5,10 \mathrm{mg})$ combined with indapamid $(2.5 \mathrm{mg})$ can be explained by their mechanism of action. In experimental studies it was found that a diet with high fat levels leads to the development of hypertension as a result of increased education of the free radicals of oxygen (superoxide anion) that inactivate NO (Roberts et al., 2000). Studies examining the relationship between diet, activity of the sympatho-adrenal system (SAS) and the pathogenesis of hypertension in combination with obesity, confirmed the participation of the sympathetic nervous system (SNS), which dictates the necessity of taking $B$-blockers in the treatment of hypertension in these patients.

Table 3

Blood pressure and heart rate dynamics

during the course of bisoprolol/indapamid treatment (Mean \pm SD)

\begin{tabular}{lc}
\hline \multicolumn{1}{c}{ Parameters } & Values \\
\hline Systolic blood pressure prior to treatment & $168.3 \pm 26.6$ \\
Systolic blood pressure after 10-14 days of in-patient treatment & $129.5 \pm 11.9^{*}$ \\
Diastolic blood pressure prior to treatment & $100.8 \pm 12.7$ \\
Diastolic blood pressure after 10-14 days of in-patient treatment & $75.5 \pm 6.3^{*}$ \\
Mean blood pressure prior to treatment & $123.3 \pm 16.0$ \\
Mean blood pressure after 10-14 days of in-patient treatment & $93.4 \pm 6.5^{*}$ \\
Pulse blood pressure prior to treatment & $67.5 \pm 19.9$ \\
Pulse blood pressure after 10-14 days of in-patient treatment & $54.0 \pm 11.8^{*}$ \\
HR prior to treatment & $83.4 \pm 11.9$ \\
HR after 10-14 days of in-patient treatment & $75.3 \pm 6.2^{*}$ \\
\hline
\end{tabular}

Note: ${ }^{*}-\mathrm{P}<0.05$ vs levels before treatment.

The sympathetic nervous system is a target of $\beta$-blockers. It is proved that early sympathetic activation is an important predictor of morbidity and mortality. Noradrenaline is a neurohumoral transmitter SNS, it causes a lot of adverse effects, which can be neutralized by ß-blockers. An important effect is the suppression of direct cardiotoxic effects of catecholamines by reducing their release from neurons by blockade presynaptic $\beta$-adrenergic recaptors. There is evidence that the activation of $\beta$-adrenergic receptors in the myocardium can cause dysfunction and death of cardiomyocytes due to prolonged decrease in intracellular calcium levels. Catecholamines have direct effects on growth factor in cardiomyocytes, stimulate the process of hypertrophy and are trigger oxidative stress in the apoptosis program (Buemui et al., 2000).

Numerous epidemiological studies have shown a relationship between tachycardia and hypertension. Increasing heart rate is associated with many risk factors, including dyslipidemia, hyperinsulinemia, obesity, and elevated hematocrit. Tachycardia is a marker of increased activity of the sympathetic nervous system. It is known that the decrease in heart rate correlates with longer life in mammals.

Moreover, $\beta$-blockers affect the renin-angiotensin-aldosterone system (RAAS), inhibiting the release of renin by blockade of $\beta_{1}$ receptors in juxtaglomerular apparatus of the kidneys.

Bisoprolol is a $\beta$-blocker with a high degree of cardioselectivity, from which this value is 1:75. Bisoprolol does not effect the level of atherogenic fractions of lipids (triglycerides, cholesterol, low-density lipoproteins) in the long reception (Ostroumova and Maksimov, 2012; Knjaz'kova, 2013).

A 13-month study in hypertensive patients taking bisoprolol at a dose of 5-10 mg, did not register statistically significant changes in cholesterol, cholesterol of low-density lipoproteins and cholesterol of high-density lipoproteins (Neutel, 2011).

Thus, the combination of bisoprolol with indapamid is able to improve endothelial function due to the presence of its antioxidant properties. An important role in this combination is played by indapamid, which, unlike other diuretics has a direct vasodilator action. We assume the following mechanisms of vasodilating effect of indapamid:

1) indapamid accumulates in the vascular wall and inhibits the entry of calcium ions in to the vascular smooth muscle cells, which leads to reduction in them of intracellular calcium and the decrease of vascular resistance (the effect of similar to calcium channel blockers);

2) stimulation of the synthesis of prostaglandin $\mathrm{I}_{2}$ (prostacyclin) and prostaglandin $\mathrm{E}_{2}$ that have a vasodilating effect;

3 ) reduction of the sensitivity of the arterial wall to catecholamines and angiotensin II (London, 2004).

The main negative effects of diuretics - hypokalemia and adverse effect on metabolism of glucose, lipids and purines. The least impact on carbohydrate and lipid metabolism is produces by indapamid (Svishhenko, 2000). 
Thus, the assessment of endothelial function and pro-inflammatory cytokines activity allows one to optimize the scheme of differrentiated prescription of therapy in hypertensive patients.

\section{Conclusions}

A positive result in the treatment of hypertensive patients with overweight and obesity using the combination of antihypertensive drugs (bisoprolol at a dose of $2.5,5,10 \mathrm{mg}$ with indapamid at a dose of $1.5,2.5 \mathrm{mg}$ ) is associated with improved endothelial function. The latter is manifested by an increase in the level of nitrites and nitrates, enhanced activity of endothelial NO-synthase activity and a simultaneous decrease of inducible NO-synthase.

This combination of antihypertensive drugs reduces oxidative stress, which is expressed in decrease in the 8-isoprostane levels as well as decrease in SOD and catalase activity. At the same time, the conditions for preservation of functionally active NO pool are created by inhibiting the toxic peroxynitrite.

Thus, possessing pronounced antioxidant properties, reducing the symptoms of endothelial dysfunction, a combination of bisoprolol with indapamid significantly reduces the autoimmune activation level, which is manifested in the reduction of TNF- $\alpha$ ratio to its type I soluble receptor (sTNF- $\alpha$ RI).

\section{References}

Alisson, D. B., Gallagher, D., \& Heo, M. (1997). Body mass index and allcause mortality among people age 70 and over the longitudinal study of aging. International Journal of Obesity, 21, 424-431.

Allison, S. J. (2016). Oxidative stress and immune activation in hypertension. Nature Reviews Nephrology, 12, 4.

Ambrosova, T. N., Kovaljova, O. N., \& Ashcheulova, T. V. (2009). Vzaimosvjaz' aktivnosti FNO- $\alpha$ s razvitiem insulinorezistentnosti u bol'nyh s arterial'noj gipertenziej, associirovannoj s ozhireniem [Interrelation of activity $\Phi H O-\alpha$ with development of an insulinorezistentnost in patients with the arterial hypertension associated with obesity]. Liki Ukrajiny, 127, 120 123 (in Russian).

Arroyo-Espliguero, R., Avanzas, P., Quiles, J., \& Kaski, J. (2009). Creactive protein predicts functional status and correlates with left ventricular ejection fraction in patients with chronic stable angina. Atherosclerosis, 205(1), 319-324.

Ashcheulova, T. V., Zaika, M. V., \& Gerasimchuk, N. N. (2007). Vzaimosvjaz' immunnoj aktivacii i oksidativnogo stressa pri progressirovanii arterial'noj gipertenzii [Relationships between immune activation and oxidative stress in arterial hypertension progression]. Ukrainskij Terapevticheskij Zhurnal, 2, $12-15$ (in Russian).

Azra, M., \& Feely, J. (2005). Arterial stiffness is related to systemic inflammation in essential hypertension. Hypertension, 46, 1118-1122.

Bautista, L. E., Veram, L. M., \& Arenas, I. A. (2005). Independent association between inflammatory markers (C-reactive protein, interleukin 6 and TNF-alpha) and essential hypertension. Journal of Human Hypertension, 19, 149-154.

Buemui, M., Corica, F., \& Marino, D. (2000). Cardiovascnlar remodeling, apoptosis and drugs. American Journal of Hypertension, 13, 450-454.

Chaudhary, M., \& Chaudhary, S. (2017). Unravelling the lesser known facets of angiotensin II type 1 receptor. Current Hypertension Reports, $19,1$.

Chow, B. S. M., \& Allen, T. J. (2016). Angiotensin II type 2 receptor (AT2R) in renal and cardiovascular disease. Clinical Science, 130(15), 1307-1326.

Dyer, A. R., Elliott, P., \& Shipley, M. (1994). Body mass index and association of sodium and potassium with blood pressure in intersalt. Hypertension, 23, 729-736.

Gerasimchuk, N. N. (2008). Vazoaktivnyj pul oksida azota u bol'nyh s arterial'noj gipertenziej i izbytochnoj massoj tela [Vasoactive nitric oxide pool at overweight patient with arterial hypertension]. Circulation and Haemostasis, 3, 21-26 (in Russian).

Knjaz'kova, I. I. (2013). Terapevticheskaja jeffektivnost' bisoprolola u bol'nyh so stabil'noj stenokardiej. Zdorov'ja Ukrajiny, 17, 13-15 (in Russian).

Kovaljova, O. N., Ashcheulova, T. V. (2002). Faktor nekroza opuholej- $\alpha$. Klinicheskoe issledovanie aktivnosti pri arterial'noj gipertenzii [Tumor necrosis factor- $\alpha$. Clinical trial of activity at arterial hypertension]. Imunologija ta Alergologija, 4, 64-66 (in Russian).

Kovaljova, O. N., Ashcheulova, T. V., \& Gerasimchuk, N. N. (2015). Vzaimosvjaz' immunnoj aktivacii i oksidativnogo stressa u bol'nyh gipertonicheskoj bolezn'ju i ih korrekcija kombinirovannoj antigipertenzivnoj terapiej [Relationship of immune activation and oxidative stress in patients with hypertension and their correction combined antihypertensive therapy]. Nauchnye Vedomosti Belgorodskogo Gosudarstvennogo Universiteta Medicina Farmacija, 213, 52-59 (in Russian).

Kovaljova, O. N., Ashcheulova, T. V., Gerasimchuk, N. N., \& Safargalina-Kornilova, N. A. (2015). Rol' oksidativnogo stressa v stanovlenii i progressirovanii gipertonicheskoj bolezni [Role of oxidative stress in the formation and progression of hypertensive disease]. Nauchnye Vedomosti Belgorodskogo Gosudarstvennogo Universiteta Medicina Farmacija, 201, 5-10 (in Russian).

Kovaljova, O. N., Belovol, A. N., \& Zaika, M. V. (2005). Rol' oksidativnogo stressa $\mathrm{V}$ kardiovaskuljarnoj patologii [Role of an oxidative stress in cardiovascular pathology]. AMN Ukrajiny, 11(4), 660-670 (in Russian).

Kovaljova, O. N., Shapovalova, S. A., \& Gerasimchuk, N. N. (2005). Kombinirovannaja terapija arterial'noj gipertenzii [Combination therapy of hypertension]. Plejada, Harkiv (in Russian).

Lahera, V., Cachofeiro, V., \& Heras, N. (2011). Interplay of hypertension, inflammation, and angiotensin II. American Journal of Hypertension, 24, 1059-1059.

Li, H., Zhu, X., Wang, A., \& Wang, G. (2012). Co effect of insulin resistance and biomarkers of inflammation and endothelial dysfunction on hypertension. Hypertension Research, 35(5), 513-517.

London, G. M. (2004). Efficacy of indapamide $1.5 \mathrm{mg}$, sustained release, in the lowering of systolic blood pressure. Journal of Human Hypertension, $18,9-14$.

Neutel, J., 2011. Combination therapy in hypertension. Springer Healthcare, California, USA.

Ostroumova, O. D., \& Maksimov, M. L. (2012). Bezopasnost' primenenija bisoprolola u bol'nyh s sochetannoj patologiej: Klinicheskaja jeffektivnost' i jekonomicheskaja celesoobraznost' [Safety in usage of bisoprololo in patients with complex pathology: Clinical effectiveness and economic rationale]. Consilium Medicum, 14(1), 64-66 (in Russian).

Privalova, E. V. (2013). Arterial'naja gipertenzija: Zashhita organov-mishenej vs prognoz. Al'ternativnyj vybor ili zven'ja odnoj cepi? [Arterial hypertension. Protection of target organs versus prognosis. Alternative choice or links in a single chain?]. Consilium Medicum, 15(5), 14-18 (in Russian).

Roberts, C., Vaziri, N., \& Wang, X. (2000). Enhanced NO inactivation and hypertension induced by a high-fat, refined-carbohydrate diet. Hypertension, 36(3), 423-429.

Ruilope, L. M. (2005). Renal function and cardiovascular risk in hypertensive patients. Journal of Hypertension, 23, 1787-1788.

Sjostrom, C. D., \& Lissner, L. (1997). Relationships between changes in body composition and changes in cardiovascular risk factors: The SOS International Study. Obesity Research, 5(6), 519-530.

Stamler, R., Stamler, J., \& Griim. R. (1987). Nutritional therapy for high blood pressure: Final repot of a four-year randomized controlled trial the Hypertension Control Program. American Medical Association, 257(11), 1484-1491.

Svishhenko, E. P. (2000). Vlijanie indopresa (indapamida) na sutochnyj profil' arterial'nogo davlenija i nejrogumoral'nye faktory ego reguljacii [Influence of indapamid on daily profile of arterial tension and neurohumoral factors of its regulation]. Doktor, 4, 46-47 (in Russian).

Zahorska-Markiewicz, B., Janowska, J., Olszanecka-Glinianowicz, M., \& Zurakowski, A. (2000). Serum concentrations of TNF- $\alpha$ and soluble TNF- $\alpha$ receptors in obesity. International Journal of Obesity, 24(11), 1392-1395. 